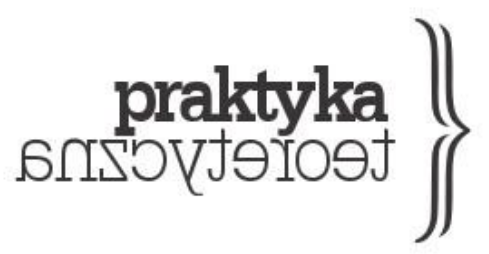

\title{
ZARZĄDZANIE RYZYKIEM. O ROLI RYNKU INSTRUMENTÓW POCHODNYCH W EKSTRAKCJI I DYSTRYBUCJI WARTOŚCI DODATKOWEJ
}

\author{
TOMASZ PLOMIŃSKI
}

\begin{abstract}
Abstrakt: Rynek derywatów, przez wiele osób uznawany za podstawową przyczynę globalnego kryzysu ostatnich lat, często interpretowany jest jako przestrzeń czysto spekulacyjnego ruchu fikcyjnego kapitału. W dwudziestym wieku zostało wypracowane teoretyczne ujęcie pomiaru kwantyfikowalnego ryzyka (w opozycji do niemierzalnej niepewności) dając kapitałowi, również dzięki serii deregulacji prawnych postępujących od lat siedemdziesiątych, nowe narzędzia do zarządzania niestabilnym z zasady procesem produkcji wartości - derywaty, czyli instrumenty finansowe umożliwiające handel ekspozycja na ryzyko, wyabstrahowaną od samych aktywów. Biorąc za punkt wyjścia Marksowskie pojęcie „kapitału fikcyjnego” i akcentując jego nieredukowalność do funkcji „kasyna kapitalistów", przedstawiamy interpretację rynku instrumentów pochodnych jako aparatu zarządzania ryzykiem ściśle powiązanego z produkcją wartości dodatkowej. Funkcjonalny charakter derywatów polega więc na 1) rozwoju technologii redystrybucji wartości dodatkowej wśród klasy kapitalistycznej i stabilizacji strumienia dochodów, 2) podporządkowaniu klasy pracującej poprzez relację długu i wtórną ekstrakcję wartości dodatkowej jako procentu z kredytu. Oba z tych zjawisk generują jednocześnie wynikające z samej zasady działania rynku derywatów sprzeczności niebezpieczne dla procesu akumulacji kapitalistycznej.
\end{abstract}

Słowa kluczowe: Marks, kapitał fikcyjny, instrumenty pochodne, kapitał finansowy, finansjalizacja. 


\section{Wprowadzenie}

Karol Marks pisał wprawdzie o kapitale finansowym w III tomie Kapitatu, ale instrumenty pochodne, czyli umowy finansowe, których wartość uzależniona jest od innego przedmiotu transakcji finansowych (może to być na przykład cena danego surowca, kurs akcji, strumień dochodów z kredytu, a nawet wskaźniki pogodowe), nie pełniły w jego czasach istotnej roli. Zasadnicza zmiana nadeszła w latach siedemdziesiątych dwudziestego wieku wraz z fala deregulacji rynku finansowego - podstawa teoretyczna dla funkcjonowania rynku derywatów powstawała na przestrzeni dwudziestego wieku za sprawą Franka Knighta (Knight 2009), Harry'ego Markowitza (Markowitz 1952), Fishera Blacka i Myrona Scholesa oraz Roberta Mertona (Black i Scholes 1973; Merton 1973)ํ. W jaki sposób możemy myśleć w kategoriach Marksowskich o tym obszarze rynków finansowych, którego funkcjonowanie wydaje się często zagadką nawet dla samych jego twórców i głównych beneficjentów? Celem tego artykułu jest zwrócenie uwagi na nieredukowalność rynku instrumentów pochodnych do roli narzędzia spekulacji poprzez wskazanie roli, jaką odgrywają w centralnym z punktu widzenia Kapitału procesie wytwarzania wartości dodatkowej, oraz uwidocznienie sprzeczności wynikających ze sposobu ich funkcjonowania.

Artykuł składa się z czterech części: w pierwszej funkcjonowanie derywatów zostanie przedstawione w kontekście używanego przez Marksa pojęcia kapitału fikcyjnego, by pokazać, że wbrew często powtarzanej opinii nie polegaja one jedynie na spekulacji nieistniejącym kapitałem (sam Marks, pisząc o kapitale fikcyjnym, nie ma bowiem na myśli jego „pozornego” działania). Następnie poruszona zostanie kwestia transferu i zarządzania ryzykiem jako najczęściej przywoływana racja istnienia rynku derywatów. W części trzeciej skupię się na roli sekurytyzacji i derywatów w przechwytywaniu wartości od gospodarstw domowych. W czwartej części opiszę sprzeczności, które tkwią w zasadzie funkcjonowania derywatów jako jednocześnie stabilizatorów ryzyka i katalizatorów spekulacji, oraz przedstawię umocowanie części z nich w kredytach hipotecznych. Artykuł zakończy podsumowanie i wskazanie możliwych dalszych kierunków badań.

\footnotetext{
${ }^{1}$ Rozwój racjonalności ryzyka w dwudziestym wieku, wraz z przekształceniami w obrębie kapitalizmu, zasługuje na osobne opracowanie. Proces wyłaniania się prawdopodobieństwa jako sposobu opisywania rzeczywistości, który pozwolił na postęp w dziedzinie nauk ścisłych, a następnie społecznych, opisuje od strony historycznej Peter Bernstein (Bernstein 1996). Rozwój nowoczesnej teorii finansów i jego wpływ na kształt późnego kapitalizmu analizuje z kolei Donald MacKenzie (MacKenzie 2008).
} 


\section{Derywaty a kapitał fikcyjny}

Karol Marks w III tomie Kapitału korzysta z określenia „kapitał fikcyjny”. Pojawia się ono jedynie dwa razy (w tym raz w przytaczanym przez niego cytacie), jednak wskazuje na sposób, w jaki Marks rozumie funkcjonowanie finansów. W jego charakterystyce sektora finansowego obieg pieniężny jest częścią cyrkulacji kapitału, która jest fikcyjna w takim sensie, w jakim pisze on o fetyszu lub mistyfikacji - procesy kształtowania cen i przenoszenia praw własności na rynkach finansowych sa jak najbardziej realne, jednak skrywaja w sobie relacje wartości. Z tego powodu działanie sektora finansów, choćby w największym stopniu objęte było zasadą spekulacji (a więc wymianą kapitalistów nakierowaną tylko na odniesienie zysku, nie na produkcje), jest nadal związane z produkcją wartości dodatkowej ${ }^{2}$. Ta intuicja Marksa o nieredukowalnej zależności między rynkami finansowymi a produkcją wartości dodatkowej posłuży nam za punkt wyjścia do analizy bardziej złożonego, właściwego późnemu kapitalizmowi rynku instrumentów pochodnych - rynku, na którym obiektem wymiany nie sa już prawa do towarów lub strumieni pieniężnych, ale same prawa (lub zobowiązania) do ich nabycia w danym terminie, za określoną cenę. Należy przy tym podkreślić, że kapitał finansowy sam w sobie nie jest źródłem wartości dodatkowej - ta powstaje jedynie w sferze produkcji.

Powróćmy jednak na chwilę do Marksowskiego pojęcia kapitału fikcyjnego. W XXIX rozdziale III tomu Kapitału pojawia się stwierdzenie: „Wraz z rozwojem kapitału przynoszącego procent i systemu kredytowego wszelki kapitał zdaje się podwajać, a niekiedy nawet potrajać wskutek tego, że ten sam kapitał albo chociażby to samo roszczenie wierzycielskie występuje w ręku różnych osób w różnych formach. Większa część tego »kapitału pieniężnego« jest zupełną fikcją" (Marks 1959, 17). Fikcyjność opisywanego „kapitału” (zastosowany tutaj cudzysłów jest znaczący) polega na tym, że procent z obligacji lub kredytu wydaje się tożsamy z wartością dodatkową (zgodnie $\mathrm{z}$ aktualnym jak nigdy spostrzeżeniem Marksa: „każdy określony i regularny dochód pieniężny występuje jako procent z kapitału, bez względu na to, czy pochodzi, czy też nie pochodzi z kapitału” [Marks 1959, 10]), podczas gdy mamy tu do czynienia jedynie z zobowiązaniem, umową dotyczącą kapitału, który dopiero w przyszłości ma wytworzyć wartość dodatkową ${ }^{3}$. Finansowy obrót tytułami własności sprawia, że ,ginie wszelki ślad związku z rzeczywistym procesem pomnażania wartości kapitału, a wyobrażenie o kapitale jako o wartości, która automatycznie sama się pomnaża, jeszcze się wzmacnia" (Marks 1959, 13). Konsekwencją tego jest utowarowienie umów i praw własności, a z drugiej strony multiplikacja występowania tych

\footnotetext{
2 Zwraca na to uwage, opisując Marksowski kapitał fikcyjny, także David Harvey (Harvey 2013).

3 „Wszystkie te papiery reprezentują w gruncie rzeczy jedynie zakumulowanie roszczenia, tytuły prawne, do przyszłej produkcji” (Marks 1959, 15).
} 
samych środków („wszystko podwaja się i potraja i staje się wprost urojeniem” [Marks 1959, 20]). Jak zobaczymy, derywaty w pewnym sensie doprowadzaja do skrajności logikę zaprezentowaną przez Marksa - utowarowienie będzie dotyczyć samego ryzyka zawieranych umów, a wielopiętrowe konstrukcje bazujące na tych samych aktywach osiagną wartości liczone w setkach bilionów dolarów ${ }^{4}$.

Fikcyjność kapitału finansowego nie oznacza jednak, że pozostaje on bez wpływu na rzeczywista produkcję wartości dodatkowej. Cédric Durand zestawia pojęcie kapitału fikcyjnego użyte u Marksa i Hayeka, wskazując, że dla tego drugiego skutki działania sektora finansowego to jedynie marnotrawstwo i nieefektywna alokacja zasobów, z kolei spojrzenie Marksa na ten problem jest bardziej zniuansowane i uwzględnia wpływ akumulacji finansowej na realny proces akumulacji wartości (Durand 2017, 174-175). Ta obserwacja jest kluczowa dla naszego sposobu analizy rynku derywatów - Marks rzeczywiście, opisawszy „fikcyjność” podwójnego lub potrójnego wliczania tej samej wartości przez kapitał finansowy, w dalszej części rozdziału XXIX poświęca uwagę temu, w jaki sposób kredyty i weksle uczestniczą w reprodukcji kapitału i realizacji wartości (Marks 1959, 26-33).

Korzystanie z pojęcia kapitału fikcyjnego często wiąże się z akcentowaniem spekulacyjnego charakteru rynków finansowych i ich redukcją do roli „kasyn”, w których gracze wymieniają się zgodnie z zasadami gry stałą ilością środków. W ten sposób wydaje się aplikować to pojęcie François Chesnais - rekonstrukcja Marksowskiego kapitału fikcyjnego prowadzi u niego do potraktowania rynku derywatów właśnie w ten sposób: „skala handlu derywatami jest jednocześnie wyrazem »finansowego kasyna« w najczystszej postaci” (Chesnais 2017, 182-183). Taka interpretacja nie tylko uniemożliwia spojrzenie na funkcjonalny charakter derywatów w akumulacji kapitalistycznej, ale także, co pokazaliśmy wcześniej, nie wyczerpuje charakterystyki kapitału fikcyjnego przedstawionej przez Marksa. Kolejnym potencjalnym źródłem nieporozumień jest wskazywane przez Costasa Lapavitsasa swobodne podejście do analizy danych finansowych, które może skutkować przecenianiem rozmiarów i potęgi rynków finansowych albo - równie często - lekceważeniem realnych zysków inkasowanych przez ten sektor (Lapavitsas 2013, 132). Naszym celem jest raczej, za Lapavitsasem, zbadanie, „jak i dlaczego finanse zaczynają formować odrębny system wpływający na tempo i kierunek akumulacji kapitalistycznej jako całości”. System finansowy,

\footnotetext{
${ }^{4} \mathrm{~W}$ czerwcu 2016 roku wielkość rynku instrumentów pochodnych OTC (off the counter), czyli zawieranych bezpośrednio między dwoma podmiotami, osiagnęła 544 biliony dolarów wartości nominalnej lub 20,7 biliona dolarów wartości rynkowej (Bank for International Settlements 2016). Dla porównania, światowy PKB w 2016 roku to około 75 bilionów dolarów (dane za Bankiem Światowym, http://databank.worldbank.org/data/download/GDP.pdf).
} 
a w przypadku tego artykułu rynek derywatów, nie będzie więc traktowany po prostu jako pasożyt, ale raczej jako integralny element reżimu akumulacji (Lapavitsas 2013, 410).

Oba aspekty kapitału fikcyjnego są widoczne, jeśli spojrzymy na sposób, w jaki funkcjonuje rynek instrumentów pochodnych. Trzy podstawowe zastosowania derywatów na współczesnych rynkach finansowych to spekulacja, arbitraż oraz hedging. Pierwsze z nich stanowi najczęstszy przedmiot krytyki rynku instrumentów pochodnych jako rynku, na którym obraca się fikcyjnie generowanymi sumami pieniędzy w grze o sumie zerowej zyski jednego uczestnika zawsze są bilansowane przez straty innych. To spekulacja jest najczęstszą aktywnością instytucji finansowych (banki inwestycyjne, fundusze hedgingowe) na rynku. Motywem podejmowania aktywności na rynku derywatów jest w tym przypadku po prostu odniesienie zysku kosztem innych aktorów (szacując oczekiwaną wypłatę względem ponoszonego ryzyka) poprzez zawierane kontrakty. Nie zamierzamy lekceważyć tej funkcji, transakcje czysto spekulacyjne stanowią bowiem większość na rynku ${ }^{5}$, jednak jeśli ograniczylibyśmy się tylko do niej, nie bylibyśmy w stanie wytłumaczyć wpływu derywatów na wytwarzanie wartości dodatkowej. Jak się jednak okaże, spekulacja nie jest jedyną ani nawet pierwotną racją istnienia derywatów. Arbitraż to z kolei działanie polegające na wykorzystaniu różnicy w wycenie tych samych aktywów i na osiagnięciu w ten sposób wolnego od ryzyka zysku. Ma on miejsce, kiedy istnieje możliwość jednoczesnego zakupu (po niższej cenie) i sprzedaży (po wyższej) produktu finansowego powiązanego z tym samym aktywem. Sama możliwość istnienia arbitrażu wynika z niedoskonałości rynku i niedokładności wyceny instrumentów ${ }^{6}$ - w teorii wyceny aktywów i konstruowania instrumentów pochodnych zazwyczaj zakłada się brak arbitrażu na racjonalnym rynku (McNeil, Frey i Embrechts 2005). W końcu trzecim zastosowaniem instrumentów pochodnych jest tak zwany hedging - w przeciwieństwie do spekulacji, upatrującej zysku w wysokim ryzyku, polega on na minimalizacji ryzyka (Chance i Brooks 2010, 12). Zasada działania hedgingu opiera się na istnieniu uczestniczek rynku o przeciwnych celach. Tego typu umowy były zawierane już w czasach starożytnych, kiedy uczestnicy handlu ustalali cenę sprzedaży lub zakupu towaru z pewnym wyprzedzeniem (zabezpieczając się na przykład

\footnotetext{
5 Trudno jest określić dokładne proporcje, jednak kierując się podziałem podmiotów działających na rynkach na instytucje finansowe (występujące na rynku przede wszystkim jako spekulanci) oraz pozafinansowe (firmy korzystające $z$ derywatów często w celu bilansowania mikroi makroekonomicznego ryzyka), można przyjąć, że spekulacja stanowi ok. 90\% rynku derywatów (Lapavitsas 2013, 61). Trudności w rozgraniczeniu obu funkcji zostaną omówione w następnym akapicie.

${ }^{6}$ A także nieusuwalnych ograniczeń technologicznych - bigh frequency trading, czyli wykorzystanie algorytmów do zawierania transakcji na przestrzeni ułamków sekundy opiera się właśnie na fakcie, że przepływ informacji na rynkach finansowych odbywa się w coraz krótszym, ale z konieczności niezerowym czasie, co powoduje minimalne niedokładności w wycenie instrumentów, a w konsekwencji możliwość arbitrażu (zob. Ratajczak 2015).
} 
przed wpływem klęsk nieurodzaju na ceny zboża) (Chance 2008). Hedging nie może być więc redukowany do kasynowej gry rynkowej - jest użyteczny z punktu widzenia produkcji wartości dodatkowej, wiąże się bowiem $z$ ryzykiem podejmowanym w sektorach pozafinansowych (w tym produkcyjnym).

Wymienione funkcje instrumentów pochodnych są możliwe do wyraźnego rozdzielenia tylko i wyłącznie w idealnym modelu. W rzeczywistości trudno nakreślić granicę między spekulacja a hedgingiem. Wyjaśnia to Tony Norfield, argumentując, że hedgingu i spekulacji nie można oddzielić według danych na podstawie klasyfikacji agentów jako „komercyjnych” i „niekomercyjnych” albo „finansowych” i „niefinansowych”, nie dlatego jednak, że ciężko zmierzyć albo określić spekulację, ale dlatego, że każdy uczestnik rynku musi po prostu w pewnym stopniu korzystać z hedgingu, a także czasami spekulować. Instytucje finansowe, kojarzone zazwyczaj ze spekulacją, potrafia wykorzystywać hedging do ograniczenia źródeł ryzyka, zaś firmy „produkcyjne”, funkcjonujące na rynku derywatów przede wszystkim w celu zabezpieczenia płynności, nierzadko spekuluja własnymi środkami tak, aby osiagnąć dodatkowy zysk. Co więcej, za spekulację można uznać nawet rezygnację z hedgingu (który zawsze wiąże się z pewnym kosztem, a więc zaniechanie zakładu także oznacza podjęcie ryzyka) (Norfield 2012).

Niezależnie od wymienionych trudności współistnienie obu funkcji instrumentów pochodnych pokazuje, że nie da się tego rynku sprowadzić tylko do „fikcyjnej” spekulacji w następnych częściach pracy skupimy się na tym, w jaki sposób wpływają one na produkcję wartości dodatkowej poprzez dwa zasadnicze procesy: dystrybucję ryzyka i proliferację kredytu hipotecznego.

Jak widać, funkcjonowanie rynku instrumentów pochodnych można odnieść do Marksowskiego pojeccia kapitału fikcyjnego, o ile przyjmiemy je w takim rozumieniu, w jakim formułuje je sam autor - a więc nie tylko oderwanego od rzeczywistego procesu produkcji wartości kasyna kapitalistów, ale także czynnika istotnego dla całego reżimu akumulacji kapitalistycznej. W następnych częściach zostaną przedstawione dwa zasadnicze zastosowania derywatów, które odpowiadają drugiemu z aspektów kapitału fikcyjnego.

\section{Derywaty jako środek transferu i zarządzania ryzykiem}

Mając na myśli ryzyko, korzystamy z przyjętego w teorii decyzji rozróżnienia między ryzykiem a niepewnościa. Przyjmując, że nie jesteśmy w stanie deterministycznie określić efektów określonych działań, jesteśmy skazani na niepewność. Istnieje jednak możliwość ilościowego oszacowania prawdopodobieństwa określonych zdarzeń - wtedy mówimy o ryzyku. Ryzyko więc jest takim rodzajem niepewności co do przyszłych zdarzeń, który przez pomiar można ująć w ramy aparatu matematycznego (Knight 2009, 19-20). Taki sposób myślenia 
o niepewności i ryzyku daje podstawę współczesnej teorii finansów - oczekiwania co do przyszłej wartości danych aktywów mogą być określane konkretną kwotą lub przedziałem.

Skoro jesteśmy w stanie poprzez ryzyko określić prawdopodobieństwo występowania zdarzeń oraz oczekiwane ceny, następnym krokiem w tej abstrakcji jest wycena i wymiana samego ryzyka. Dick Bryan i Michael Rafferty piszą o derywatach właśnie jako o utowarowionym ryzyku, czyli samym prawdopodobieństwie danego zdarzenia lub zmiany ceny. Instrumenty pochodne umożliwiają więc kapitalistom swobodną wymianę samą ekspozycją na ryzyko, a nie tylko nośnikami wartości (towarami, pieniędzmi, papierami wartościowymi itd.). Sieć zależności, która powstaje na skutek tej wymiany, ma charakter systemowy, przenika współczesny globalny kapitalizm i - według Bryana i Rafferty’ego odgrywa w nim kluczową rolę w obiegu wartości (Bryan i Rafferty 2006). Jednocześnie odseparowanie heterogenicznych czynników ryzyka (ryzyko wynikające z niepewności co do przyszłej produkcji lub sprzedaży towarów, wahań kursów walut, konfliktów zbrojnych, klęsk żywiołowych i innych) od ich źródeł i grupowanie ich oraz ucieleśnianie w instrumentach finansowych pozwalaja na utowarowienie samego ryzyka oraz sprowadzenie go do abstrakcyjnej, ilościowej formy (Sotiropoulos i Lapatsioras 2014, LiPuma i Lee 2005). W następstwie tego obciążenie ryzykiem może być dystrybuowane w obrębie klasy kapitalistycznej. Mnogość kontraktów jest więc w pewnym sensie fikcyjna względem realnych warunków produkcji, jednak ich sieć ma oplatać globalny kapitał i odciążać najbardziej narażone miejsca.

Funkcjonowanie rynku derywatów, a więc ryzyka w utowarowionej, abstrakcyjnej postaci wymaga osiąnnięcia współmierności. Polegałaby ona, według określeń Bryana i Rafferty'ego, na dwóch mechanizmach:

1. Wiązanie (binding) - wartość przyszła jest łączona z obecną wartością aktywa.

2. Mieszanie (blending) - na rynku określana jest relacja pomiędzy różnymi formami ryzyka.

Instrumenty pochodne rozwijają więc opisywany już przez Marksa finansowy mechanizm „przenoszenia” wartości w czasie (tak jak w przypadku weksli i kredytu), a jednocześnie pozwalają na utworzenie homogenicznej przestrzeni ryzyka, w której klęski żywiołowe da się wycenić na tej samej zasadzie co wahania akcji1. Wycena jeszcze niewyprodukowanej wartości

\footnotetext{
${ }^{7}$ Operacjonalizacją owej przestrzeni ryzyka zajmuje się właśnie dwudziestowieczna teoria decyzji i finansów - rachunek prawdopodobieństwa pozwala na określanie ryzyka na podstawie przeszłych zdarzeń, a dalej na transpozycję określonego prawdopodobieństwem ryzyka na wartości pieniężne.
} 
to oczywiście część definicji Marksowskiego kapitału fikcyjnego i cecha charakterystyczna finansjalizacji w ogóle (kładą na to nacisk Lapavitsas [2013] i Durand [2017]). To właśnie drugi z mechanizmów, czyli homogenizacja ryzyka, zmienia zasady gry - od teraz każde ryzyko dzięki upowszechnieniu derywatów może zostać odsprzedane w celu ustabilizowania produkcji albo kupione przez żądnego zysku spekulanta. Ponadto znacznie zmniejsza się koszt zarządzania ryzykiem - ponoszony jest jedynie koszt związany ze zmianą wartości aktywa, a nie całej jego wartości ${ }^{8}$. Z perspektywy produkcji wartości dodatkowej derywaty można więc interpretować jako technologię, która pozwala kapitałowi przemysłowemu na pewniejsze planowanie produkcji, łańcucha dostaw czy realizacji wartości. O ich powszechnym zastosowaniu niech świadczy fakt, że 94\% z 500 największych firm świata (ISDA 2009) uczestniczy w rynku instrumentów pochodnych, aby bilansować różne źródła ryzyka.

Donald MacKenzie w pracy An Engine, Not a Camera: How Financial Models Shape Markets śledzi historię powstania rynku derywatów jako rynku abstrakcyjnego ryzyka. Chicago Board of Trade, jedna z najstarszych giełd futures i opcji, założona w celu handlu kontraktami na zboże, a więc stabilizacji warunków produkcji rolnej, wydawała się w latach sześćdziesiątych dwudziestego wieku pozbawiona przyszłości. Po wprowadzeniu minimalnych cen zboża hedging stracił na znaczeniu, dodatkowo istniał wymóg prawny dotyczący rzeczywistego przekazania aktywa zabezpieczanego przez kontrakt, co ograniczało działalność spekulacyjna. W planach zarządu giełdy zaczęła się pojawiać koncepcja emitowania derywatów finansowych powiązanych z kursami akcji lub walut, plany te ograniczały jednak polityczne restrykcje i sztywne kursy walut gwarantowane przez układ z Bretton Woods. Dopiero legitymizacja tych pomysłów przez ekonomistów takich jak Milton Friedman i ostateczne odejście od parytetu złota w 1971 roku pozwoliły na kaskadowy rozrost obszaru instrumentów pochodnych (MacKenzie 2008, 143-156). Stopniowo zaczęły się pojawiać coraz bardziej egzotyczne formy derywatów, całkowicie unieważniając wcześniejsze ograniczenia dotyczące „hazardowych” kontraktów - ryzyko huraganu mogło od teraz być wyceniane tak samo jak zmiana ceny buszla pszenicy. W ten sposób narodził się rynek zdolny do transferu dowolnego ryzyka, ale też będący nieograniczonym polem do spekulacyjnych zakładów.

\footnotetext{
${ }^{8}$ Aby więc, dla przykładu, zabezpieczyć się na wypadek zmiany ceny baryłki ropy, nie trzeba już kupować prawa do jednej baryłki za 50 dolarów - wystarczy nabyć kontrakt terminowy ustalający cenę zakupu baryłki ropy w przyszłości (instrument typu future) za ułamek tej ceny.
} 


\title{
3. Derywaty jako środki ekstrakcji wartości dodatkowej od gospodarstw domowych
}

Instrumenty pochodne wraz z sekurytyzacją, czyli emisją papierów wartościowych zabezpieczonych aktywami (takimi jak na przykład hipoteka), odgrywają zasadniczą rolę w rozroście rynku kredytów hipotecznych. Rozrastającemu się warstwowo zapośredniczeniu relacji między dłużnikiem a wierzycielem Cédric Durand poświęca miejsce w swojej książce Fictitious Capital: How Finance Is Appropriating Our Future. Opisuje on, jak kredyt hipoteczny udzielany gospodarstwom domowym - podstawowy budulec instrumentów pochodnych, które doprowadziły do rozrostu bańki spekulacyjnej - dzięki sekurytyzacji mógł być odsprzedawany przez banki uczestniczkom rynku finansowego. W ten sposób bank już nie był bezpośrednio uzależniony od spłaty kredytu przez gospodarstwo domowe, ryzyko z tym związane ponosił bowiem ktoś inny (Durand 2017, 48-51). Nowo obowiązujący proces przedstawia się następująco:

\begin{abstract}
Rozpoczynając od strony pożyczkobiorcy, kolejne z głównych ogniw łańcucha to: 1) dystrybucja długów pośród gospodarstw domowych i firm albo emisja instrumentów pochodnych; 2) grupowanie ich w pakiety; 3) stworzenie papierów wartościowych zabezpieczonych aktywami, bazując na pakietach produktów finansowych; 4) łączenie tych pakietów, w tym umów opcji, w celu uformowania swojego rodzaju finansowego mille-fenille [...]; 5) sprzedaż inwestorom na rynkach finansowych (Durand 2017, 163).
\end{abstract}

Deregulacja i użycie takich instrumentów jak MBS (mortgage-backed securities) - pozwalających na obrót wierzytelnością hipoteczną na rynku wtórnym - oraz CDS (credit default swaps) które umożliwiają spekulację na podstawie szacowanego prawdopodobieństwa niespłacenia zobowiązania - pozwoliło więc w USA na gigantyczny wzrost zadłużenia gospodarstw domowych (od poniżej 45\% do 1985 roku do ponad 95\% w 2007 roku), ponieważ nieopłacalne wcześniej ze względu na wysokie ryzyko umowy kredytowe naraz stały się intratne na wtórnym rynku finansowym ${ }^{9}$. Wypłacalność każdego robotnika i robotnicy jest od tego czasu starannie mierzona za pomoca wyrafinowanych modeli statystycznych ryzyka kredytowego, następnie zaś łączona z innymi, wyceniana i obracana na rynku instrumentów pochodnych, które, jak widzimy, były niezbędnym elementem do rozpropagowania kredytów hipotecznych na niespotykaną dotąd skalę.

\footnotetext{
9 Dynamikę wzrostu zadłużenia gospodarstw domowych w stosunku do PKB można prześledzić na przykład na podstawie danych Banku Rozliczeń Międzynarodowych: https://pl.tradingeconomics.com/united-states/households-debt-to-gdp.
} 
Międzynarodowy Fundusz Walutowy w swoim raporcie bezpośrednio przyznawał, że „gospodarstwa domowe sa buforem bezpieczeństwa ostatniej instancji” (shock absorber of last resort), dodając jednak bezpośrednio po tym: „jednocześnie nowi odbiorcy ryzyka finansowego muszą nauczyć się, jak zarządzać nowo nabytymi ryzykami” (IMF 2005, 89). „Zarządzać ryzykiem” mają więc teraz zarówno inwestujący kapitaliści, jak i zaciagający zobowiązania robotnicy - oczywiście na całkowicie odmiennych zasadach. O ile tym pierwszym zarządzanie ryzykiem pozwala na osiaganie zysków, ci drudzy moga jedynie starać się uchronić przed bankructwem i wybierać spośród możliwości oferowanych im przez pierwszych $^{10}$. Ta asymetria jest oczywiście bliźniaczo podobna do tej związanej z ,wolnymi umowami” zawieranymi na rynku pracy. Marks wyszydzał „podwójną wolność” robotników: wolnych jako wolne osoby rozporządzające siłą roboczą będąca ich towarem, a zarazem wolnych od posiadania jakichkolwiek innych towarów na wymianę (Marks 1951, 179). W opisywanym tutaj przypadku wolność robotnika do zarządzania swoim zadłużeniem mistyfikuje co najmniej dwa zjawiska: po pierwsze, kapitał dokonuje próby podporządkowania robotnika poprzez zobowiązanie kredytowe, jednocześnie tworząc dodatkowe źródło popytu na towary; po drugie, relacja zadłużenia stanowi wtórną relację wyzysku, w której reprodukcja siły roboczej sama jest źródłem wartości dodatkowej (Bryan $\mathrm{i}$ in. 2009). Mianowicie część wytworzonej wartości, która jest wypłacana robotnikom na pokrycie kosztów ich reprodukcji, zostaje zagospodarowana przez zobowiązanie do spłaty kredytu (przede wszystkim hipotecznego) oraz pomniejszona o procent $z$ tego kredytu przekazany kapitałowi. Dostrzega to Maurizio Lazzarato w Making of an Indebted Man, piszac: „To, co media nazywaja »spekulacjąu, przedstawia maszynę służąca do przechwytywania i żerowania na wartości dodatkowej w warunkach stworzonych przez dzisiejszą akumulację kapitalistyczną" (Lazzarato 2012, 21). Kapitał osiaga więc dodatkową porcję wartości dodatkowej, przywłaszczając sobie część pensji robotniczej w relacji kredytu, a rynek derywatów umożliwia kapitałowi ekspansję tej relacji. Od teraz robotnik jest zobowiązany wobec kapitalisty nie tylko umową o pracę, ale także umową kredytową, a klasa kapitalistyczna zarabia dwa razy, na wyzysku pracy i procencie od kredytu.

\section{Sprzeczności rynku instrumentów pochodnych}

Oba przedstawione zastosowania instrumentów pochodnych zawierają w sobie sprzeczności, które moga uderzać w akumulację kapitalistyczna. Pierwsza $z$ nich jest związana

\footnotetext{
10 Sotiropoulos i Lapatsioras mówią w tym kontekście o wytwarzaniu nowej racjonalności, Lazzarato o nowych formach podmiotowości (Sotiropoulos i Lapatsioras 2014, Lazzarato 2012).
} 
z równoczesnością występowania hedgingu minimalizującego ryzyko i niekontrolowanej, potęgującej niestabilność rynków finansowych spekulacji, druga wynika z niebezpieczeństw zakotwiczenia olbrzymiej puli derywatów w kredytach hipotecznych.

Jak pokazano wcześniej, derywaty pełnią dwuznaczną rolę z punktu widzenia funkcjonowania kapitalizmu - nawet jeśli przyjmuje się wykładnię rodem z podręczników finansów, zgodnie z którą instrumenty pochodne służą zarządzaniu ryzykiem, a więc pozwalaja na większą kontrolę nad zjawiskami rynkowymi i pozarynkowymi (nad ich wpływem na rynki finansowe), co najmniej od 2008 roku powszechnie znane jest ich drugie oblicze - „dzikich bestii finansów” (Steinherr 2000) czy „finansowej broni masowej zagłady” (Buffett 2002). Całościowe spojrzenie na derywaty, ich związek z funkcjonowaniem sektora produkcyjnego, finansowego i z wybuchającymi kryzysami ujawnia sprzeczność obecną w samej zasadzie ich działania. Świadectwem tej sprzeczności jest polemika między Bryanem i Raffertym oraz Norfieldem. Ci pierwsi, szczególnie w ich wspólnej książce Capitalism with Derivatives, opisuja derywaty jako przestrzeń spajająca system finansowy (a także kapitalistyczny w szerszym znaczeniu), zapewniająca mu stabilność i dokonująca transformacji niepewności w mierzalne ryzyko, przeliczone na jednostki pieniężne. Tak mocne postawienie akcentu na ,amortyzacyjna” rolę derywatów prowadzi ich do uznania rynku instrumentów pochodnych za „nowy standard złota” - miałby on stanowić stabilne źródło globalnej wyceny aktywów i, jak pieniądz kruszcowy, mediować jako ogólny ekwiwalent w czasach znacznych wahań walut (Bryan i Rafferty 2008). Norfield krytykuje jednak sprowadzanie derywatów do roli pieniądza: przede wszystkim wskazuje na skrajną niestabilność cenową i nietrwałość derywatów, a także na fakt, że same w sobie są one przecież zawsze określane przez pieniądz i tym samym uzależnione od niego (Norfield 2012) ${ }^{11}$. Z jego perspektywy derywaty to przede wszystkim narzędzie spekulacji, zrodzone za sprawa spadającej pod koniec dwudziestego wieku krańcowej stopy zysku. Autorów dzieli nie tylko stanowisko teoretyczne, ale także po części moment publikacji. Prace Bryana i Rafferty'ego opublikowane do 2008 roku znacznie mocniej akcentuja stabilizacyjny charakter rynku derywatów, współcześnie jednak niszczycielski wpływ spekulacji (odbywającej się głownie za pośrednictwem instrumentów pochodnych) jest powszechnie

\footnotetext{
${ }^{11}$ W swojej późniejszej odpowiedzi na krytykę ze strony Norfielda Bryan i Rafferty przenoszą ciężar argumentacji na płynność rynku derywatów - niezależnie od tego, jak bardzo wartość określana w ten sposób jest nietrwała, łatwość, z jaką instrumenty pochodne pozwalają wycenić każde z aktywów, nadaje im właściwości zbliżone do pieniądza (Bryan i Rafferty 2012). Również ten argument zostaje odrzucony przez Norfielda, dowodzącego, że rolą derywatów nie jest wcale określanie wartości przez "płynny ekwiwalent" (Norfield 2013a); niekonsekwencja w określaniu derywatów raz to jako pieniądza, a raz ,jakby pieniądza” zostaje wytknięta autorom także przez Chesnais'ego (Chesnais 2017, 186-188). Niezależnie jednak od tego, jak oceniamy zaproponowane przez Bryana i Rafferty'ego ujęcie derywatów jako pieniądza, nie unieważnia to ich opisu rynku instrumentów pochodnych jako przynajmniej w zamyśle stabilizującego globalny kapitał dzięki transferowi ryzyka.
} 
uznany - w kontekście wpływu finansjalizacji i derywatów na środowisko naturalne mówi się np. o kapitalizmie katastroficznym (Zob. Büscher 2010, Rojas 2016). Po kryzysie finansowym z 2008 roku wiemy wszakże, że spekulacja derywatami jest destrukcyjna nie tylko dla środowiska, ale także dla samego kapitału. Działanie spekulacyjne bowiem korzysta na niepewności rynków finansowych i pogłębia ją w nadziei na premię od wysokiego ryzyka. Co więcej, nawet jeśli założymy, że określanie ryzyka bazuje na skutecznej teorii i aparacie statystycznym $^{12}$, pozostaje wiele miejsca na nadużycia wynikające z pokusy zaniżania ratingu, czyli fałszywej oceny ryzyka konkretnych instrumentów. W jaki jednak sposób obie funkcje stabilizacja akumulacji kapitalistycznej przez hedging i spekulacja maksymalizująca (a także zafałszowująca) ryzyko - są ze sobą powiązane i dlaczego mówimy tu o koniecznej sprzeczności?

Tony Norfield, pokazując współistnienie hedgingu i spekulacji na rynku, zwraca uwagę na ich toksyczną symbiozę. Z jednej strony, hedging jako narzędzie ograniczania różnego rodzaju ryzyka dla kapitału był kluczowy, jeśli chodzi o powstanie rynku derywatów (historia Chicago Board of Trade zaczyna się w połowie dziewiętnastego wieku z potrzeby kontroli cen dostaw zboża [Chance 2008, 8-9]). Jednocześnie precyzyjny hedging wymaga odpowiedniego nasycenia rynku różnymi konfiguracjami portfela aktywów - innymi słowy, dużej liczby uczestników rynku, oferujących różne pod względem składu i wyceny instrumenty. Wynika to z faktu, że aby doszło do hedgingu, na rynku musi być dostępny „lustrzany” odpowiednik kontraktu, czyli możliwość zysku realizowanego w dokładnie odwrotnej sytuacji i wysokości. Warunek ten z kolei może zostać zapewniony jedynie przez znaczny udział w rynku derywatów spekulantów, którzy w poszukiwaniu zysku na krótkoterminowych transakcjach wypełniają rynek swoimi kontraktami. Ponadto co do zasady kontrakt hedgingowy ma dłuższy czas realizacji niż kontrakt spekulacyjny kapitalista zabezpieczający swój kapitał robi to w dłuższym horyzoncie czasowym niż spekulant, który w tym samym czasie, korzystając z chwilowych wahań rynku, wykonuje o wiele więcej transakcji (Norfield 2012). Tak więc spekulacyjny rozrost rynku derywatów jest wpisany w samą zasadę jego funkcjonowania.

Należy w tym miejscu wspomnieć o jeszcze jednym mechanizmie związanym z działaniem spekulacyjnym, jednocześnie ukazującym jego destrukcyjny charakter - dźwigni finansowej, której stosowanie określa się lewarowaniem. Mechanizm ten polega na wykorzystaniu obcych środków w celu zwiększenia zysku. W przypadku instrumentów pochodnych oznacza to wykupienie umów o zwielokrotnionej wartości poprzez zaciagnięcie zobowiązania lub opłacenie jedynie części wartości umowy depozytu. W ten sposób,

\footnotetext{
${ }^{12}$ Każde rozwiązanie tego typu kryje za sobą szereg założeń, które, jeśli przyjrzeć się im z bliska, mogą okazać się nad wyraz optymistyczne lub po prostu empirycznie fałszywe. Krytykę dominującego na rynku derywatów modelu Blacka-Scholesa przeprowadza Donald MacKenzie (MacKenzie 2013).
} 
dysponując określonym kapitałem, można zainwestować kilkunasto-, a nawet kilkudziesięciokrotnie wyższą kwotę. Jednocześnie wzrasta jednak ryzyko niewypłacalności spekulanta - narzędzia mające teoretycznie służyć do jego ograniczenia stają się tykająca bomba - a każde zdarzenie nieobjęte hedgingiem na rynku powoduje znacznie poważniejsze konsekwencje ${ }^{13}$.

Sprzeczności te możemy określić jako endogeniczne, bowiem lokują się w obrębie samego kapitału - obieg ryzyka między kapitalistami, choć teoretycznie ma na celu zabezpieczenie płynności, z konieczności generuje destrukcyjne dla kapitalizmu zjawiska związane $z$ rozrastającą się spekulacją.

Trzecia ze sprzeczności wiąże się z klasowym charakterem ryzyka. Opisana wcześniej „wolność” robotnika czy też - jak pisze Lazzarato - „człowieka zadłużonego” do zarządzania swoim długiem pozwala na stworzenie olbrzymiego rezerwuaru dla instrumentów bazujących na kredytach hipotecznych, ale jest jednocześnie obciążająca dla kapitału. Jak już wspomnieliśmy, do określenia ryzyka niewypłacalności każdego dłużnika zostaje zaprzęgnięty zaawansowany aparat matematyczny, jednak żywa praca, tak samo jak w relacji wyzysku, nie daje się zredukować do czystej wartości liczbowej. System kredytowy, w którym „ostatecznym buforem bezpieczeństwa” są gospodarstwa domowe, jest więc kolosem na glinianych nogach - to, co zapewnia źródło dodatkowego zysku kapitałowi, może być (czego byliśmy świadkami w 2008 roku) przyczyną jego zapaści. Opisywana sprzeczność nie jest więc tym razem strukturalną cechą kapitału, można ją raczej nazwać egzogeniczna, wynika bowiem z klasowego charakteru relacji zadłużenia - tam, gdzie kapitał nowymi metodami próbuje podporządkować sobie klasę robotnicza, pojawia się także potencjalne ognisko oporu. Społeczeństwo posłusznych kredytobiorców jest niezbędne do utrzymania tego sposobu akumulacji ${ }^{14}$.

\section{Podsumowanie}

Pokazaliśmy, że derywaty nie pełnią jedynie funkcji spekulacyjnej, nie służą wyłącznie wymianie fikcyjnych papierów wartościowych między uczestnikami rynku, ale odgrywaja istotną rolę w procesie kapitalistycznej produkcji. Rola ta jest dwojaka: z jednej strony można o derywatach myśleć jako o technologii pozwalającej stabilizować warunki funkcjonowania kapitalisty na rynku, planowania dostaw oraz realizacji wartości. Funkcja ta może

\footnotetext{
${ }^{13}$ W literaturze ekonomicznej mówi się w tym kontekście o endogenicznych źródłach ryzyka systemowego i o akceleratorze finansowym (zob. Battinson, Delli Gatti i in. 2012).

14 Osobną kwestią jest funkcjonowanie oszczędności klasy pracującej na rynkach finansowych - istotna jest tu rola ubezpieczeń oraz funduszy, również emerytalnych - wykracza ona jednak poza, z konieczności okrojony, zakres treści tego artykułu.
} 
być rozumiana jako „intensywny” czynnik pomnażania wartości. Z drugiej strony, sekurytyzacja i zaprzęgnięcie derywatów do zarządzania zadłużeniem klasy robotniczej (instrumenty powiązane $\mathrm{z}$ kredytami hipotecznymi oraz, w mniejszym stopniu, konsumenckimi, fundusze emerytalne) wtórnie redukują koszty poniesione przez kapitał na opłacenie siły roboczej - byłby to „ekstensywny” wymiar pomnażania wartości, związany ze zmniejszeniem udziału opłaconego czasu pracy robotnika.

Nasza próba myślenia o związku narzędzi finansowych z wytwarzaniem wartości dodatkowej opiera się na ujęciu kapitału jako całości - kapitału, którego nie sposób już tak łatwo rozdzielić na przemysłowy, handlowy czy finansowy i w ramach którego relacja wyzysku nie ogranicza się do indywidualnej relacji robotnik-kapitalista (za Marksem: „kapitał jest sam w sobie wspólnym kapitatem całej klasy" [Marks 1957, 401]). Inżynieria finansowa może więc być interpretowana raczej jako technologia umożliwiająca zwiększenie (na dwa wspomniane sposoby) proporcji, a także ilości wartości dodatkowej przechwytywanej przez kapitalistę (ponownie - rozumianego nie jako jednostka w bezpośredniej relacji robotnikkapitalista, ale część złożonej całości). Podobnie jak środki produkcji nie sa same w sobie źródłem wartości dodatkowej, a jedynie umożliwiaja produkcję wartości dodatkowej osiagnniętej na drodze wyzysku pracy żywej i ją zwiększaja, tak praca sektora finansowego i operacje na instrumentach pochodnych nie tworzą wartości, ale mogą (nie musza): 1) intensyfikować produkcję poprzez ułatwienie sektorowi produkcyjnemu funkcjonowania w warunkach niepewności; 2) przenosić wartość w obrębie klasy kapitalistycznej ${ }^{15}$, a także przechwytywać ja wtórnie poprzez procent od środków utrzymania klasy robotniczej; w końcu 3) stanowić narzędzie dyscyplinujące klasę robotniczą przez przenoszenie na nia ryzyka kapitału i uzależnianie jej bytu od środków z kredytu.

Przedstawiona w tym tekście charakterystyka rynku derywatów nie jest w żadnej mierze wyczerpująca. Celowo pominięte zostały takie jej aspekty jak kwestie prawnych regulacji rynku instrumentów pochodnych, udział instytucji państwowych w rynku, kwestia powiązania cen derywatów z polityką monetarną $i$ inne. Wiele z nich nie doczekało się jeszcze satysfakcjonującej analizy przeprowadzonej z perspektywy marksistowskiej.

Gwałtowny wzrost popularności instrumentów pochodnych nie świadczy o radykalnych przemianach w sposobie funkcjonowania globalnego kapitalizmu - uwypukla raczej logikę ryzyka, która stopniowo rozwija się w myśli ekonomicznej i na rynkach finansowych od początku dwudziestego wieku. Rola jej nie jest jedynie usprawnienie spekulacji i ustanowienie globalnego kasyna dla kapitalistów, ale raczej stworzenie warunków do wzrostu rentowności kapitału oraz do zwiększenia wyzysku robotników na drodze relacji

\footnotetext{
${ }^{15} \mathrm{Na}$ ten aspekt zjawiska zwraca uwagę Norfield, pisząc o imperializmie finansowym - instrumenty finansowe, w tym derywaty, pozwalają na geograficzny transfer wartości dodatkowej w kierunku państw imperialistycznych (Norfield 2013).
} 
zadłużenia. Zarazem jednak rynek derywatów zawiera w sobie dwie nieusuwalne sprzeczności - z jednej strony jednoczesne procesy ograniczania (hedging) i generowania (spekulacja) ryzyka potęgują kryzysowe tendencje kapitału, z drugiej zaś, jako narzędzia kontroli i wtórnego wyzysku klasy robotniczej, uwikłane są w napięcia nieuchronnie wynikające z nieprzewidywalnego, niedającego się zredukować do precyzyjnie określanych miar charakteru żywej pracy. 


\section{Wykaz literatury}

Battiston, Stefano, Domenico Delli Gatti, Mauro Gallegati, Bruce Greenwald i Joseph E. Stiglitz. 2012. „Liaisons Dangereuses: Increasing Connectivity, Risk Sharing, and Systemic Risk." Journal of Economic Dynamics and Control 36 (8): 1121-1141. doi:10.1016/j.jedc.2012.04.001.

Bernstein, Peter L. 1996. Against the Gods: The Remarkable Story of Risk. New York: John Wiley $\&$ Sons.

Black, Fischer i Myron Scholes. 1973. „The Pricing of Options and Corporate Liabilities.” Journal of Political Economy 81 (3): 637-654. doi:10.1086/260062.

Bryan, Dick, Randy Martin i Michael Rafferty. 2009. „Financialization and Marx: Giving Labor and Capital a Financial Makeover." Review of Radical Political Economics 41 (4): 458472. doi:10.1177/0486613409341368.

Bryan, Dick i Michael Rafferty. 2006a. Capitalism with derivatives: a political economy of financial derivatives, capital and class. Houndmills, Basingstoke, Hampshire-New York: Palgrave Macmillan.

Bryan, Dick i Michael Rafferty. 2006b. „Money in capitalism or capitalist money?” Historical Materialism 14 (1): 75.

Bryan, Dick i Michael Rafferty. 2006c. „Financial Derivatives: The New Gold?” Competition \& Change 10 (3): 265-282. doi:10.1179/102452906X114375.

Bryan, Dick i Michael Rafferty. 2007. „Financial Derivatives and the Theory of Money.” Economy and Society 36 (1): 134-158. doi:10.1080/03085140601089861.

Bryan, Dick i Michael Rafferty. 2012. „Why We Need to Understand Derivatives in Relation to Money: A Reply to Tony Norfield." Historical Materialism 20 (3): 97-109. doi:10.1163/1569206X-12341253.

Bryan, Dick, Michael Rafferty i Chris Jefferis. 2015. „Risk and Value: Finance, Labor, and Production." South Atlantic Quarterly 114 (2): 307-329. doi:10.1215/00382876-2862729.

Büscher, Bram. 2010. „Derivative Nature: Interrogating the Value of Conservation in »Boundless Southern Africa«." Third World Quarterly 31 (2): 259-276. doi:10.1080/01436591003711983.

Buffett, Warren. 2002. „Chairman's letter.” W Berkshire Hathaway Annual Report 2002.

Chance, Don M. i Robert Edwin Brooks. 2010. An Introduction to Derivatives and Risk Management. Mason, Ohio: South-Western Cengage Learning.

Chesnais, Francois. 2016. Finance Capital Today: Corporations and Banks in the Lasting Global Slump. Historical materialism book series 131. Leiden-Boston: Brill.

Durand, Cédric. 2017. Fictitious Capital: How Finance Is Appropriating Our Future. London-New York: Verso.

Greenspan, Alan. 1999. „Remarks by Chairman Alan Greenspan Financial Derivatives Before the Futures Industry Association, Boca Raton, Florida." https://www.federalreserve.gov/boarddocs/speeches/1999/19990319.htm

Harvey, David. 2013. A Companion to Marx's Capital. Volume Two. London: Verso.

International Monetary Fund. 2005. Global Financial Stability Report: Market Developments and Issues. Washington, DC: International Monetary Fund. http:/ /www.imf.org/ External/Pubs/FT/GFSR/2005/01/index.htm.

International Swaps and Derivatives Association (ISDA). 2009. ISDA Research Notes. 2009 Derivatives Usage Survey. New York: ISDA.

https://www2.isda.org/attachment/MTY4Mw==/ISDA-Research-Notes2.pdf

Knight, Frank H. 2009. Risk, Uncertainty and Profit. Kissimmee, Fla: Signalman. 
Lazzarato, Maurizio. 2012. The Making of the Indebted Man: An Essay on the Neoliberal Condition. Los Angeles: Semiotext(e).

LiPuma, Edward i Benjamin Lee. 2005. „Financial Derivatives and the Rise of Circulation.” Economy and Society 34 (3): 404-427. doi:10.1080/03085140500111931.

Lobo-Guerrero, Luis. 2010. Insuring Security: Biopolitics, Security and Risk. New York: Routledge.

MacKenzie, Donald. 2008. An Engine, Not a Camera: How Financial Models Shape Markets. Inside Technology. Cambridge: MIT.

Markowitz, Harry. 1952. „Portfolio Selection.” The Journal of Finance 7 (1): 77-91. doi:10.2307/2975974.

Marks, Karol. 1951. Kapitał. Tom I. Tłum. zbiorowe. Warszawa: Ksiazka i Wiedza.

Marks, Karol. 1957. Kapitat. Tom III. Cześś piernsza. Tłum. zbiorowe. Warszawa: Ksiazka i Wiedza.

Marks, Karol. 1959. Kapitał. Tom III. Cz̨eś́ druga. Tłum. zbiorowe. Warszawa: Ksiazka i Wiedza.

Martin, Randy. 2017. An Empire of Indifference. Durham: Duke University Press.

Martin, Randy, Michael Rafferty i Dick Bryan. 2008. „Financialization, Risk and Labour.” Competition \& Change 12 (2): 120-132. doi:10.1179/102452908X314849.

Medeiros Carneiro, Ricardo de, Pedro Rossi, Guilherme Santos Mello i Marcos Vinicius Chiliatto-Leite. 2015. „The Fourth Dimension: Derivatives and Financial Dominance.” Review of Radical Political Economics 47 (4): 641-662.

Merton, Robert C. 1973. „Theory of Rational Option Pricing.” The Bell Journal of Economics and Management Science 4 (1): 141. doi:10.2307/3003143.

Norfield, Tony. 2012. „Derivatives and Capitalist Markets: The Speculative Heart of Capital.” Historical Materialism 20 (1): 103-132. doi:10.1163/156920612X634735.

Norfield, Tony. 2013a. „Derivatives, Money, Finance and Imperialism: A Response to Bryan And Rafferty." Historical Materialism 21 (2): 149-168.

Norfield, Tony. 2013b. „Value Theory and Finance.” W Research in Political Economy. Red. Paul Zarembka. 28: 161-195. Emerald Group Publishing Limited. doi:10.1108/S0161$7230(2013) 0000028007$.

Ratajczak, Mikołaj. 2016. „Towards a political economy of algorithms: High-frequency trading and the efficient market hypothesis." W Digital Ecosystems. Smart Economy and Innovation. Red. Katarzyna Śledziewska. Warszawa: DELab UW. http://www.delab.uw.edu.pl/wp-content/uploads/2016/11/DE_Smart_Economy.pdf

Rojas, Isaac. 2016. „Mainstreaming Financialization of Nature.” ECO 52 (2). http://www.cbdalliance.info/en/wp-content/uploads/2016/04/ECO-2-SBSTTA20.pdf.

Sotiropoulos, Dimitris P. i Spyros Lapatsioras. 2014. „Financialization and Marx: Some Reflections on Bryan's, Martin's and Rafferty's Argumentation." Review of Radical Political Economics 46 (1): 87-101. doi:10.1177/0486613413488072.

Sotiropoulos, Dimitris P. 2015. „Hilferding on Derivatives.” The European Journal of the History of Economic Thought 22 (1): 77-96. doi:10.1080/09672567.2012.708769.

Steinherr, Alfred. 2000. Derivatives: The Wild Beast of Finance: a Path to Effective Globalisation? New York: John Wiley.

Wigan, Duncan. 2009. Financialisation and Derivatives: Constructing an Artifice of Indifference. Competition \& Change 13 (2): 157-172. doi:10.1179/102452909X417033. 
Tomasz Płomiński - doktorant w Zakładzie Historii Filozofii Nowożytnej IF UW, redaktor afiliowany czasopisma naukowego Praktyka Teoretycz̨na. Zajmuje się głównie krytyką ekonomii politycznej, teorią wartości i finansjalizacja.

\title{
DANE ADRESOWE:
}

Instytut Filozofii Uniwersytetu Warszawskiego

Ul. Krakowskie Przedmieście 3

00-097 Warszawa

EMAIL: tplominski@gmail.com

CYTOWANIE: Płomiński, Tomasz. 2017. Zarządzanie ryzykiem. O roli rynku instrumentów pochodnych w ekstrakcji i dystrybucji wartości dodatkowej. Praktyka Teoretyczna 3 (25): 176-193.

DOI: $10.14746 /$ prt.2017.3.6

\section{AUTHOR: Tomasz Płomiński}

TITLE: Risk management. On the role of derivatives in extraction and distribution of surplus value

\begin{abstract}
The derivatives market, widely understood as a primary cause of a recent global crisis, is commonly seen as a space of purely speculative movement of fictitious capital. In the course of the 20th century, a theory of quantifiable risk (as opposed to unquantifiable uncertainty) has been developed, giving capital, together with a series of deregulations from 1970s onwards, a new toolset for managing the precarious nature of value production: namely, derivatives, a financial instrument enabling the trading of risk exposure abstracted from the assets themselves. Taking Marx's notion of "fictitious capital" with its irreducibility to a mere "casino for capital" as a starting point, we aim to present an interpretation of the derivatives market as an apparatus of risk management that is strictly connected to the production of surplus value. The functional character of derivatives is seen as: 1. a means of subordination of the working class in a form of debt relation and secondary extraction of surplus value as credit interest, 2. technological advancement of value redistribution among the capitalist class and stabilization of income flow. Both phenomena are tied to the inherent contradictions of the derivatives market that are potentially harmful to the very process of capitalist accumulation.
\end{abstract}

KEYWORDS: Marx, fictitious capital, derivatives, financial capital, financialization. 